\title{
AGE ESTIMATION BASED ON THE STAGE OF MINERALIZATION OF THIRD MOLARS ON ORTHOPANTOMOGRAMS
}

\author{
ESTIMATIVA DE IDADE BASEADO NO ESTAGIO DE MINERALIZAÇÃO DE \\ TERCEIROS MOLARES EM RADIOGRAFIAS PANORÂMICAS
}

\author{
Leticia de Oliveira TONIN ${ }^{1}$; Noemia Luisa Pittelli LEITE $^{2}$; Rodrigo GALO ${ }^{3}$; \\ Ricardo Henrique Alves da SILVA
}

1. Bolsista de Iniciação Científica (FAPESP), USP - Faculdade de Odontologia de Ribeirão Preto, Ribeirão Preto, SP, Brasil. 2. Especialista em Odontologia Legal, USP - Faculdade de Odontologia de Ribeirão Preto, Ribeirão Preto, SP, Brasil; 3. Professor Doutor, UFVJM - Universidade Federal dos Vales do Jequitinhonha e Mucuri, Diamantina, MG, Brasil; 4. Professor Doutor, USP - Faculdade de Odontologia de Ribeirão Preto, Ribeirão Preto, SP, Brasil. ricardohenrique@usp.br.

\begin{abstract}
The aim of this study was to evaluate the correlation among chronological age, sex and stages of mineralization of third molars using orthopantomograms in a Brazilian population. For such purpose, 1,200 orthopantomograms of 9-20-year-old individuals (654 females and 546 males) were examined using as reference the Nicodemo's table of mineralization chronology of permanent teeth among Brazilians. Estimated mean ages, standard deviations, standard errors and percent age distribution in each mineralization stage were established. Mann-Whitney and Kruskal-Wallis $(\mathrm{p} \leq 0.05)$ nonparametric tests were used to verify the influence of sex in the stages of mineralization of the third molars. The development of maxillary and mandibular and right and left third molars was similar in all stages. Females presented a more advanced stage of mineralization of third molars than males. Statistically significant difference in third molar development between males and females was found in stage 4 in teeth $18(\mathrm{p}=0.008), 28(\mathrm{p}=0.029), 38$ $(\mathrm{p}=0.010)$ and $48(\mathrm{p}=0.046)$. The results suggest that the development of third molars is similar in both sexes, regardless of the quadrant of dental arch and the tooth mineralization stage table employed in this study was applicable for using third molars as parameters for age estimation in the studied population.
\end{abstract}

KEYWORDS: Forensic anthropology. Forensic dentistry. Radiology.

\section{INTRODUCTION}

Forensic age estimation of skeletons and corpses for identification purposes has been a conventional feature of Forensic Sciences, with great relevance from ethical and legal perspectives (KARAARSLAN et al., 2010). Age determination of living or dead individuals is a major issue and is frequently the first step in the whole identification process (SCHEMELING et al., 2007). The forensic dentist may contribute for determination of people's age by using direct methods based on clinical examination, which involve the observation of the number of erupted teeth, chronology of eruption and general conditions of the teeth; or indirect methods based on the analysis of intraoral and extraoral radiographs, mainly for observation of the stages of mineralization of the teeth (ARAÚJO et al., 2010), which is one of the most commonly used methods for age estimation (BRKIC; MILICEVIC; PETROVECKI, 2006).

Despite the scientific evidence supporting the use of dental age for estimation of chronological age, it should be considered that there is variation from one individual to another. The difficulties in the study of third molar development and in its clinical or forensic application are especially related to the variability in the formation of these teeth because the specific composition and shape of teeth are conditioned by their functions (ARAÚJO et al., 2010). In addition, age estimation becomes more difficult after the age of 14 because the mineralization of most teeth is completed around this age (HERAS; FORTEA; ORTEGA, 1987). Therefore, the third molar has a substantial importance because it is the only tooth that continues developing after this age (HERAS; FORTEA; ORTEGA, 1987). The shape of third molars varies greatly and, because of the late eruption, they have well preserved characteristics and are mainly used for identification of individuals around 18 years of age (AMARITI et al., 1999). However, some divergence is observed when studies with different populations are compared, which reinforces the importance of further research to evaluate the actual applicability of the method (KULLMAN et al., 1996).

There are numerous studies conducted in this subject on different populations of the world. The majority of the study results are from the European continents. In view of the variations which occur worldwide, the European study results may not give accurate chronological age of an individual when used in the South American 
continent. Then, the aim of this study was to evaluate the correlation among chronological age, sex and stages of mineralization of third molars using orthopantomograms and create a database for the Brazilian population.

\section{MATERIAL AND METHODS}

In order to comply with the Brazilian Ethical Standards in research on humans, the study protocol was submitted to the Ethics Committee of Ribeirao Preto School of Dentistry, University of São Paulo, and was approved under the protocol \#2010.1.399.58.4.

A total of 1,200 orthopantomograms of individuals aged between 9 and 20 years old (654 females and 546 males) obtained from radiographic archives were analyzed for this study. The orthopantomograms were randomly chosen from the Department of Oral Radiology, School of Dentistry of Ribeirão Preto, University of São Paulo. The orthopantomograms were produced from April 2010 to March 2011. The chronological age of each subject was calculated based on reported date of birth and date of the radiographic examination contained on the orthopantomograms. The chronological ages were not revealed at the moment of the analysis. The criteria for inclusion in the individuals were the availability in their clinical records of an orthopantomography of appropriate quality, and no history of medical or surgical disease that could affect the presence and development of third molars. From the initial sample, we excluded cases with any missing image, due to poor visualization or due the extraction of any third molars.

The stage of mineralization of the third molars was analyzed on the orthopantomograms according to the table of mineralization chronology of permanent teeth among Brazilians conceived by Nicodemo (NICODEMO, 1969) in order to estimate the chronological age and compare age estimation between sexes. In each radiograph, the third molars were classified as belonging to one of the 8 Nicodemo's stages of mineralization. Then, the estimated age was compared with the chronological age. The existence of statistically significant difference in age estimation between sexes in each one of the mineralization stages was also verified.

Impacted wisdom teeth were excluded from the analysis. Mesially and distally angulated third molars were classified as impacted. Wisdom teeth with an unclear direction of emergence also were not included in the analysis. Image deformity affecting third molar visualization, hypodontia, or orthopantomograms showing obvious dental pathology also consisted of as exclusion criteria.

All digital radiographs were taken with the Veraviewepocs $2 \mathrm{D}^{\circledR}$ (J. Morita, Kyoto, Japan). The Veraviewepocs $2 \mathrm{D}^{\circledR}$ orthopantomograms images were taken with a high-resolution CCD sensor (32bit microprocessor) (J. Morita, Kyoto, Japan) with exposure parameters $7.4 \mathrm{~s}, 64 \mathrm{kV}$, and $8.9 \mathrm{~mA}$. One well-trained examiner observed the radiographs after a period of calibration without the knowledge of age and gender. To test intra-examiner reliabilities, different staged the development of teeth were checked on 100 orthopantomograms. The examiner repeated the process after 1 month (intraexaminer), and Cohen's kappa test was performed to calculate the intra-examiner agreements.

The homogeneity of the collected data was assessed and a non-normal distribution was observed. Mann-Whitney and Kruskal-Wallis (5\%) nonparametric tests were used to verify the influence of sex in the stages of mineralization of the third molars. Statistical analysis was performed using the SPSS software for Windows, version 12.0 (SPSS, Inc, Chicago, IL, USA).

\section{RESULTS}

Intra-observer differences were not found in the repeated observing of a subsample of 100 radiographs $(\mathrm{P}>0.05)$. Intra-observer consistency was rated at $94 \%$. Age distribution by stage of mineralization of third molars, sex and tooth number is presented in Table 1. Orthopantomogram distribution according to age and sex is shown in Table 2. Distribution of female and male subjects according to the stage of mineralization of third molars is shown in Table 3. Table 4 presents the mean age, standard deviation, standard error of the mean, and minimal and maximal age (in years) according to sex and stage of mineralization of third molars.

Overall, there were statistically significant differences between males and females in age estimation in all mineralization stages of third molars, regardless of the quadrant of dental arch [18 $(\mathrm{P}=0.008) ; 28 \quad(\mathrm{P}=0.029) ; 38 \quad(\mathrm{P}=0.010)$ and; 48 $(\mathrm{P}=0.046)]$. However, considering each stage separately, it was found that sexual dimorphism did not occur in all cases, and significant differences referred only to stage 4 for all four third molar tooth numbers (Table 4). No statistically significant differences $(\mathrm{P}>0.05)$ were observed in the mineralization stage between the maxillary and mandibular or between left and right third molars. 
Table 1. Age distribution by stage of mineralization of third molars, sex and tooth number, Ribeirão Preto, Brazil.

\begin{tabular}{lccccc}
\hline \multirow{2}{*}{ Stage } & \multirow{2}{*}{ Sex } & \multicolumn{4}{c}{ Age (years) } \\
\cline { 3 - 6 } & & Tooth 18 & Tooth 28 & Tooth 38 & Tooth 48 \\
\hline \multirow{2}{*}{ S1 } & Male & $9.71(0.89)$ & $9.48(0.65)$ & $9.64(0.85)$ & $9.61(0.82)$ \\
& Female & $9.56(0.88)$ & $9.46(0.75)$ & $9.63(0.85)$ & $9.46(0.84)$ \\
S2 & Male & $10.08(0.75)$ & $10.21(0.87)$ & $9.90(0.76)$ & $9.88(0.84)$ \\
& Female & $10.15(1.05)$ & $10.32(1.06)$ & $10.17(1.31)$ & $10.45(1.28)$ \\
S3 & Male & $11.06(1.22)$ & $11.00(1.01)$ & $10.94(1.13)$ & $10.91(1.12)$ \\
& Female & $11.17(1.36)$ & $11.16(1.25)$ & $10.95(1.67)$ & $11.07(1.19)$ \\
S4 & Male & $12.7(1.56)$ & $12.81(1.48)$ & $12.64(1.67)$ & $12.53(1.41)$ \\
& Female & $13.38(1.96)$ & $13.43(2.00)$ & $13.26(1.86)$ & $12.97(1.62)$ \\
S5 & Male & $15.23(1.58)$ & $15.21(1.67)$ & $15.06(1.70)$ & $14.94(1.60)$ \\
& Female & $15.22(1.91)$ & $15.22(1.71)$ & $15.06(2.02)$ & $15.08(2.04)$ \\
S6 & Male & $16.58(1.52)$ & $16.61(1.54)$ & $16.19(1.55)$ & $16.25(1.54)$ \\
& Female & $16,71(1.88)$ & $16.60(1.89)$ & $16.59(1.89)$ & $16.47(1.87)$ \\
S7 & Male & $19.24(1.03)$ & $18.40(1.14)$ & $18.16(1.07)$ & $18.14(1.02)$ \\
& Female & $18.28(1.54)$ & $18.25(1.51)$ & $18.24(1.45)$ & $18.17(1.48)$ \\
S8 & Male & $19.31(0.91)$ & $19.14(1.02)$ & $19.02(0.93)$ & $19.35(0.83)$ \\
& Female & $19.21(1.13)$ & $19.12(1.12)$ & $19.21(1.12)$ & $19.21(1.12)$ \\
\hline
\end{tabular}

Data are expressed as mean (standard deviation).

Table 2. Distribution of orthopantomograms according to age and sex $(n=1,200)$, Ribeirão Preto, Brazil, 2014.

\begin{tabular}{cccc} 
Age (years) & Female & Male & Total \\
\hline 9 & 60 & 40 & 100 \\
10 & 51 & 49 & 100 \\
11 & 54 & 46 & 100 \\
12 & 52 & 48 & 100 \\
13 & 48 & 52 & 100 \\
14 & 64 & 36 & 100 \\
15 & 49 & 51 & 100 \\
16 & 61 & 39 & 100 \\
17 & 55 & 45 & 100 \\
18 & 49 & 51 & 100 \\
19 & 52 & 48 & 100 \\
20 & 59 & 41 & 100 \\
Total & 654 & 546 & 1,200 \\
\hline
\end{tabular}

Table 3. Distribution of female (F) and male (M) subjects according to the stage of mineralization of third molars, Ribeirão Preto, Brazil.

Stage of mineralization of third molars

\begin{tabular}{|c|c|c|c|c|c|c|c|c|c|c|c|c|c|c|c|c|}
\hline \multirow{2}{*}{$\begin{array}{l}\text { Age } \\
\text { (yrs) }\end{array}$} & \multicolumn{2}{|c|}{ S1 } & \multicolumn{2}{|c|}{$\mathrm{S} 2$} & \multicolumn{2}{|c|}{ S3 } & \multicolumn{2}{|c|}{ S4 } & \multicolumn{2}{|c|}{ S5 } & \multicolumn{2}{|c|}{ S6 } & \multicolumn{2}{|c|}{ S7 } & \multicolumn{2}{|c|}{ S8 } \\
\hline & $\mathrm{F}$ & $\mathrm{M}$ & $\mathrm{F}$ & $\mathrm{M}$ & F & $\mathrm{M}$ & $\mathrm{F}$ & $\mathrm{M}$ & $\mathrm{F}$ & $\mathrm{M}$ & $\mathrm{F}$ & $\mathrm{M}$ & $\mathrm{F}$ & $\mathrm{M}$ & $\mathrm{F}$ & $\mathrm{M}$ \\
\hline 9 & 41 & 29 & 12 & 7 & 7 & 4 & 0 & 0 & 0 & 0 & 0 & 0 & 0 & 0 & 0 & 0 \\
\hline 10 & 13 & 17 & 12 & 9 & 22 & 17 & 4 & 6 & 0 & 0 & 0 & 0 & 0 & 0 & 0 & 0 \\
\hline 11 & 6 & 4 & 5 & 5 & 16 & 21 & 23 & 16 & 4 & 0 & 0 & 0 & 0 & 0 & 0 & 0 \\
\hline
\end{tabular}




\begin{tabular}{ccccccccccccccccc}
12 & 3 & 3 & 4 & 0 & 17 & 12 & 22 & 31 & 6 & 2 & 0 & 0 & 0 & 0 & 0 & 0 \\
13 & 0 & 0 & 0 & 0 & 5 & 3 & 25 & 21 & 11 & 28 & 7 & 0 & 0 & 0 & 0 & 0 \\
14 & 0 & 0 & 0 & 0 & 2 & 0 & 21 & 17 & 28 & 11 & 11 & 8 & 2 & 0 & 0 & 0 \\
15 & 0 & 0 & 1 & 0 & 0 & 1 & 13 & 3 & 19 & 29 & 15 & 26 & 2 & 1 & 0 & 0 \\
16 & 0 & 0 & 0 & 0 & 0 & 0 & 13 & 1 & 14 & 15 & 29 & 23 & 3 & 3 & 2 & 0 \\
17 & 0 & 0 & 0 & 0 & 0 & 0 & 7 & 0 & 12 & 18 & 19 & 4 & 12 & 10 & 4 & 3 \\
18 & 0 & 0 & 0 & 0 & 0 & 0 & 0 & 4 & 8 & 7 & 18 & 13 & 14 & 17 & 9 & 10 \\
19 & 0 & 0 & 0 & 0 & 0 & 0 & 0 & 0 & 6 & 2 & 13 & 8 & 23 & 22 & 10 & 16 \\
20 & 0 & 0 & 0 & 0 & 0 & 0 & 0 & 0 & 1 & 0 & 9 & 1 & 13 & 3 & 36 & 37 \\
\hline
\end{tabular}

Table 4. Mean age, standard deviation (SD), standard error of mean (SE), maximum and minimum age according to sex and stage of mineralization of third molars, Ribeirão Preto, Brazil, 2014.

\begin{tabular}{llllllllll}
\hline Sex & Stage & S1 & S2 & S3 & S4 & S5 & S6 & S7 & S8 \\
\hline \multirow{5}{*}{ Female } & Mean & 9.54 & 10.18 & 10.95 & 13.26 & 15.06 & 16.59 & 18.25 & 19.21 \\
& SD & 0.858 & 1.313 & 1.242 & 1.868 & 2.029 & 1.895 & 1.459 & 1.127 \\
& SE & 0.108 & 0.225 & 0.149 & 0.165 & 0.194 & 0.172 & 0.176 & 0.144 \\
& Maximum & 12 & 15 & 14 & 17 & 20 & 20 & 20 & 20 \\
& Minimum & 9 & 9 & 9 & 10 & 11 & 13 & 14 & 16 \\
Male & Mean & 9.64 & 9.90 & 10.95 & 12.65 & 15.06 & 16.19 & 18.16 & 19.02 \\
& SD & 0.118 & 0.768 & 1.13 & 1.674 & 1.704 & 1.557 & 1.075 & 0.931 \\
& SE & 0.117 & 0.168 & 0.149 & 0.168 & 0.161 & 0.171 & 0.144 & 0.137 \\
& Maximum & 12 & 11 & 15 & 18 & 19 & 20 & 20 & 20 \\
\hline Kruskal-Wallis & Minimum & 9 & 9 & 9 & 10 & 12 & 14 & 15 & 17 \\
test $(\mathrm{p} \leq 0.05)$ & $p$ & 0.357 & 0.708 & 0.998 & 0.010 & 0.948 & 0.066 & 0.370 & 0.110 \\
\hline
\end{tabular}

\section{DISCUSSION}

The use of orthopantomograms for this type of analysis has advantages over other methods, as more information can be collected from the same source; the panoramic $\mathrm{x}$-ray permits the visualization of the teeth since the beginning of crown formation up to root apex closure, offering a more reliable examination (CORNÉLIO-NETO; CONÉLIO; CONCEIÇÃO, 2006); the presence of the individual is not necessary for the analysis, which provides more agility to the processes (ARAÚJO et al., 2010).

The age range established in the present study is of paramount importance because the options for age determination become more and more restrict over time, which tends to increase the intervals of age estimations (ARAÚJO et al., 2010; AMARITI et al., 1999). Dental age can be used to estimate the chronological age, serving as an important instrument for Forensic Dentistry (ANDRADE; FERREIRA, 2011). However, forensic age estimation can be challenging due to the different methods available (ORHAN et al., 2007).
At the established age range, third molar represents one of the main criteria for age determination (CANTEKIN et al., 2012). Regarding the difference between sexes, studies have pointed to a premature mineralization in females, indicating precocity in dental development (MOORREES; FANNING; HUNT, 1963; OLZE et al., 2007). However, a study performed with 2,218 subjects in Japan, South Africa and Germany showed an advanced stage of mineralization in males of approximately $1 \frac{1}{2}$ year compared with females (OLZE et al., 2007). This result was compared with those of Japanese, South-African and Germany populations and led to the conclusion that the precocity of mineralization varies among people from different countries and regions, showing the need of collecting data specific for each population (OLZE et al., 2007).

Chronological age not always represents the actual degree of development, as children of the same age may present different degrees of tooth mineralization and maturity (ANDRADE; FERREIRA, 2011). In the present study, the comparative analysis revealed that the obtained means are very similar to the intervals used by 
Nicodemo (NICODEMO, 1969) to characterize each one of the 8 stages of tooth mineralization, being therefore applicable to the studied population.

It has been reported that the mean and maximum ages in most stages of mineralization are slightly superior in the female gender, which suggest a faster development among females (CANTEKIN et a., 2012). A confirmatory result was found in a study with children from the state of Maranhão, Brazil, in which the girls presented a more accelerated formation of permanent teeth and higher mean dental ages than those of boys (KURITA et al., 2007). In another study with Caucasian Brazilians of both sexes, the teeth of females presented an earlier degree of mineralization than those of males, without significant differences between maxillary and mandibular teeth (KVAAL et al., 1995).

Additionally, it was observed in the present study that the mean ages estimated from the mineralization stages of maxillary, mandibular, right and left third molars was similar, indicating a high correlation and the possibility of using any third molar for estimation of chronological age with high success rate. A similar result was found in a study with Spanish children and young people (BOLAÑOS et al., 2003). The mean ages estimated in the present study are consistent with those of different stages of mineralization of third molars obtained in others studies (DHANJAL; BHARDWAJ; LIVERSIDGE, 2006), also using the mineralization chronology of permanent teeth.

Bolaños (BOLAÑOS et al., 2003) verified that sex presents similar age distribution and development of third molars without statistically significant differences. In another study, the radiographs of 928 female Japanese and 686 male Japanese were examined and no statistically significant difference was found in the mineralization stage based on sex or tooth position (OLZE et al., 2004).

Nicodemo (NICODEMO, 1969) suggests that the first radiographic evidence of third molar can be seen between 7 years and 6 months and 11 years, that is, in the 90-132-month-old age range. Its appearance, however, normally occurs around 9-10 years old, although the crypt of the germ of tooth 38 has been detected around the age of 5 , which is close to the age of 6 verified by other authors (BOLAÑOS et al., 2003). In the present study, in the 9-year-old age group, the mandibular third molars were at least in stage 1 of mineralization, as proposed by Nicodemo (NICODEMO, 1969). In the maxilla, the initial stages of mineralization are more hardly detected due to the more complex anatomy of the middle third of the face, which could lead to misdiagnosis of agenesis (BOLAÑOS et al., 2003). However, part of the 12-year-old sample was also in stage 1 , which indicates a slight delay. In these cases, attention should be given to the fact that if the presence of the third molar is not detected up the age of 10 , there is a $50 \%$ chance of agenesis of this tooth and this probability is confirmed in most cases after the age of 12 (BOLAÑOS et al., 2003).

Apical closure is observed in stage 8. In the present study, this feature was observed at minimal age of 16 and maximal age of 20. According to Nicodemo (NICODEMO, 1969), apical closure occurs between 18 and 20 years, that is, in the 216246-month-old age range. Despite the evidence of early mineralization, the importance of including the age of 18 in this interval should be reaffirmed for cases of forensic studies to verify a person's full legal age (PRIETO et al., 2005). It should also be reinforced that in this age range as well as in others a larger number of maxillary third molars are in earlier stages of mineralization than the mandibular third molars.

The third molar is reported to assume a very important role at the age of 18 . However, a study in which third molars of 140 North-American individuals were used for age estimation did not find correlation between dental age and skeletal age, which was justified by the non-homogeneous mineralization of the teeth (GARN; LEWIS; BONNÉ, 1962). Other authors, on the other hand, found a strong correlation between dental age and skeletal maturation, showing that regardless of the type of tooth, a dental age is closely related to the chronological age (LIVERSIDGE, 2008). Engstrom et al., (ENGSTROM, C.; ENGSTROM, H.; SAGNE, 1983) analyzed the development of third molars with respect to chronological and skeletal age, and observed correlation between chronological age and third molar development in both sexes; between chronological age and skeletal maturation; and between third molar development and skeletal maturation. Those authors suggested that a smaller number of mineralization stages associated with a longer mineralization of third molars permits a more accurate comparisons with the skeletal maturation events.

In this way, it is possible to affirm that the evaluation of the stages of mineralization of permanent teeth provides the most substantiate base for calculation of dental age, which can be correlated with the chronological age because the mineralization of teeth is less susceptible to the influence of external factors than other elements of the individual (KARAARSLAN et al., 2010; 
ANDRADE; FERREIRA, 2011; KURITA et al., 2007). Estimation of dental age can thus be a valuable instrument for forensic estimation of chronological age (ANDRADE; FERREIRA, 2011).

\section{CONCLUSIONS}

The Nicodemo's scores are applicable for estimation of age based on the stage of mineralization of third molars on orthopantomograms, regardless of the quadrant of dental arch; the analysis of the calcification stage of third molars can be an auxiliary tool to determine chronological age; and the tooth mineralization stage figure employed in this study was applicable for using third molars as parameters for age estimation in the studied population.

The data described in this study may provide a reference for forensic application, but additional studies with a larger population sample should be conducted to meet provisions of more accurate data concerning Brazilian subjects.

\section{ACKNOWLEDGEMENTS}

The authors would like to thank to Prof. Dr. Plauto Christopher Aranha Watanabe from Ribeirão Preto Dental School, University of São Paulo, for the inestimable assistance to this study and FAPESP for the financial support.

RESUMO: A identidade de uma pessoa é importante do ponto de vista ético, legal e criminal, assim, a determinação de idade é, muitas vezes, o início do processo de identificação. O objetivo do trabalho foi verificar a aplicabilidade da utilização de estágios de mineralização de terceiros molares na estimativa de idade. Para isso, foram examinadas 1200 radiografias panorâmicas de indivíduos com idade entre 9 e 20 anos, por meio da utilização dos estágios de mineralização dos terceiros molares da Tabela de Nicodemo. Foi constatada diferença estatisticamente significante no desenvolvimento do terceiro molar entre o gênero masculino e feminino no estágio 4 de mineralização dos dentes 18 $(\mathrm{p}=0,008), 28(\mathrm{p}=0,029), 38(\mathrm{p}=0,010)$ e $48(\mathrm{p}=0,046)$. Conclui-se que a tabela utilizada com os estágios de mineralização é aplicável no que se refere à utilização do terceiro molar enquanto parâmetro para estimativa de idade, na população estudada.

PALAVRAS-CHAVES: Antropologia forense. Odontologia Legal. Radiologia.

\section{REFERENCES}

AMARITI, M. L.; RESTORI, M.; DE FERRARI, F.; PAGANELLI, C.; FAGLIA, R.; LEGNANI, G. Age determination by teeth examination: a comparison between different morphologic and quantitative analyses. J Clin Forensic Med, Edinburgh, v. 6, n. 2, p. 85-89, jun., 1999. Doi:10.1016/S1353-1131(99)90205-5

ANDRADE, M.; FERREIRA, M. A. Dental and skeletal age estimates to access biological age. Int J Academic Res, Baku, v. 3, n. 6, p. 1 76-178, nov., 2011.

ARAÚJO, A. M. M.; PONTUAL, M. L. A.; FRANÇA, K. P.; BELTRÃO, R. V.; PONTUAL, A. A. Association between mineralization of third molars and chronological age in a Brazilian sample. Rev Odonto Ciênc, Porto Alegre, v. 25, n. 4, p. 391-394, dec., 2010. Doi: 10.1590/S1980-6523201000040001.

BOLAÑOS, M. V.; MOUSSA, H.; MANRIQUE, M.; BOLAÑOS, M. J. Radiographic evaluation of third molar development in Spanish children and young people. Forensic Sci Int, Lausanne, v. 133, n. 3, p. 212-219, may, 2003. Doi:10.1016/S0379-0738(03)00037-9

BRKIC, H.; MILICEVIC, M.; PETROVECKI, M. Age estimation methods using anthropological parameters on human teeth. Forensic Sci Int, Lausanne, v. 162, n. 1-3 p. 13-16, oct., 2006.

Doi:10.1016/j.forsciint.2006.06.022 
CANTEKIN, K.; YILMAZ, Y.; DEMIRCI, T.; CELIKOGLU, M. Morphologic analysis of third-molar mineralization for eastern turkish children and youth. J Forensic Sci, Lausanne, v. 57, n. 2, p. 531-534, mar., 2012. doi: 10.1111/j.1556-4029.2011.02011.

CORNÉLIO-NETO, W. L.; CONÉLIO, G. C.; CONCEIÇÃO, M. B. Estimativa de age pelos terceiros molares através de Rx: relato de caso. Rev Gaúcha Odontol. Campinas, v. 54, n. 3, p. 230-233, set-oct., 2006.

DHANJAL, K. S.; BHARDWAJ, M. K.; LIVERSIDGE, H. M. Reproducibility of radiographic stage assessment of third molars. Forensic Sci Int, Lausanne, v. 159 (Suppl.1), n. 15, p. S74-77, mar., 2006. Doi:10.1016/j.forsciint.2006.02.020

ENGSTROM, C.; ENGSTROM, H.; SAGNE, S. Lower third development in relation to skeletal maturity and chronological age. Angle Orthod, Appleton, v. 42, n. 2, p. 97-106, apr., 1983.

GARN, S.M.; LEWIS, A.B.; BONNÉ, B. Third molar formation and its developmental course. Angle Orthod, Appleton, v. 32, n. 4, p. 270-278, oct., 1962.

HERAS, S. M.; FORTEA, P. G.; ORTEGA, A. Third molar development according to chronological age in populations. Congresso de La Sociedad de Biofisica de España p. 106, 1987.

KARAARSLAN, B.; KARAARSLAN, E.; OZSEVIK, A.; ERTAS, E. Age estimation for dental patients using orthopantomographs. Eur J Dent. Ankara, v. 4, n. 4, p. 389-394, oct., 2010.

KULLMAN, L.; TRONJE, G.; TEIVENS, A.; LUNDHOLM, A. Methods of reducing observer variation in age estimation from panoramic radiographs. Dentomaxillofac Radiol, Erlangen, v. 25, n. 4, p. 173-178, sep., 1996.

KURITA, L. M.; MENEZES, A. V.; CASANOVA, M. S.; HAITER-NETO, F. Dental maturity as an indicator of chronological age: radiographic assessment of dental age in a brazilian population. J Appl Oral Sci, Bauru, v. 15, n. 2, p. 99-104, apr., 2007.

Kvaal, S. I.; Kolltveit, K. M.; Thomsen, I. O.; Solheim, T. Age estimation of adults from dental radiographs. Forensic Sci Int, Lausanne, v. 74, n. 3, p. 175-185, jul., 1995. Doi:10.1016/0379-0738(95)01760-G

LIVERSIDGE, H. M. Timing of human mandibular third molar formation. Ann Hum Biol, London, v. 35, n. 3, p. 294-321, may-jun., 2008. doi: 10.1080/03014460801971445.

MOORREES, C. F.; FANNING, E. A.; HUNT, E. E. Jr. Age variation of formation stages for ten permanent teeth. J Dent Res, Chicago, v. 42, p. 1490-1502, nov-dec., 1963.

NICODEMO, R. A. Study of the chronology of mineralization of $3^{\text {rd }}$ molars using the radiographic method, in white Brazilians of the Paraiba Valley, State of São Paulo. Rev Fac Odontol Sao Paulo, São Paulo. v. 7, n. 2, p. 419-444, 1969.

OLZE, A.; TANIGUCHI, M.; SCHMELING, A.; ZHU, B. L.; YAMADA, Y.; MAEDA, H.; GESERICK, G. Studies on the chronology of third molar mineralization in a Japanese population. Leg Med, Tokyo, v. 6, n. 2, p. 73-79, apr., 2004. Doi:10.1016/j.legalmed.2003.09.005 
OLZE, A.; VAN NIEKERK, P.; ISHIKAWA, T.; ZHU, B. L.; SCHULZ, R.; MAEDA, H.; SCHMELING, A. Comparative study on the effect of ethnicity on wisdom tooth eruption. Int J Legal Med, Heidelberg, v. 121, n. 6, p. 445-448, apr., 2007. Doi:10.1007/s00414-007-0171-9

ORHAN, K.; OZER, L.; ORHAN, A.; DOGAN, S.; PAKSOY, C.S. Radiographic evaluation of third molar development in relation to chronological age among Turkish children and youth. Forensic Sci Int, Lausanne, v. 165, n. 1, p. 46-51, mar., 2007. Doi: 10.1016/j.forsciint.2013.07.023

PRIETO, J. L.; BARBERIA, E.; ORTEGA, R.; MAGAÑA, C. Evaluation of chronological age based on third molar development in the Spanish population. Int J Legal Med, Heidelberg, v. 119, n. 6, p. 349-354, feb., 2005. Doi:10.1007/s00414-005-0530-3

SCHEMELING, A.; GESERICK, G.; REISINGER, W.; OLZE, A. Age estimation. Forensic Sci Int, Lausanne, v. 165, p. 178-181, 2007. Doi:10.1016/j.forsciint.2006.05.016 